\title{
Reference Result Fasting Status Indicator
}

National Cancer Institute

\section{Source}

National Cancer Institute. Reference Result Fasting Status Indicator. NCI Thesaurus.

Code C95386.

An indication as to whether the reference result pertains to a specimen that was taken or an observation was made when the subject was fasting. 